\title{
The Development of Badminton Smash Learning Model for Medan State University Students
}

\author{
Usman Nasution $^{1}$, Suryadi Damanik ${ }^{2}$, Asep Suharta ${ }^{3}$ \\ \{usmanejirizma@gmail.com\} \\ Faculty Of Sport Science, Medan State University, Medan ${ }^{1}$ \\ Department of Physical Education, Health And Recreation, Medan State University, Indonesia ${ }^{23}$
}

\begin{abstract}
This study aims to produce a Smash badminton punch learning model through video tutorials, as a learning media tool. Research and Development (R \& D) model development research method, the subject of this study were 60 students. This development research was conducting with the following steps: (1) preliminary study phase, (2) expert validation, (3) testing product, and (4) creating the final product. Data were collected by using instruments: (1) initial product validation, (2) observation questionnaire for trainers and material experts, and (3) student response observation sheets. The result of this study in a video tutorial video of the badminton smash punch learning model, namely: (1) basic smash learning variations without really using and using, (2) learning variations of smash blows without jumping, (3) learning variations of smash jump punches, and (4) variations smash learning in pairs.
\end{abstract}

Keywords: Learning model, tutorial video, and badminton smash.

\section{Introduction}

The factors that affect student learning outcomes, student still lack of understanding on understand the material delivered by the lecturer. According to Anne there are three stages of learning motion in the stage of learning motor movement, cognitive stage, associative stage and autonomous stage. So at this cognitive stage the lecturer must be able to convey the material well supported by good learning media. The lack of students' willingness to repeat after the lecture. In other word students who take badminton courses after running face to face on the scheduled time they average until the next meeting do not do or repeat the material that has been received. This is due to several existing learning resources that are still in the conventional form, namely thick and heavy papers in the form of books so students feel less practical and only provide temporary information. It cannot be denied that the availability of physical education learning media is still inadequate for optimal implementation of the lecture / learning process.

Badminton is a sporting branch of Indonesian pride must be disseminated and upgraded either in the community, society or at schools. Badminton a racquet sport played by two people (for single) or two opposite (for double) pairs. Similar to tennis, Badminton aims to hit the game ball through the net in order to fall in the field of opposing games that have been determined and try to prevent opponents from doing the same thing (Sofyan, 2009). Basic techniques that are the most difficult to master well is smash punch, it is because to get an accurate smash, complicate and turn off quickly the opponent's game needed the ability to 
master the very high motion skills. After students attend badminton lectures, expected to have results, namely changes in motion. Changes from makeshift abilities become the ability to play badminton with the mastery of the right punch technique.

Explanation of how to hit a smash is linked to the provision of the right learning model because in addition to functioning as a tool to convey material or interaction, also functions as a tool to achieve goals, so that the learning model is able to improve skills in a learning process. By providing the right learning model, both in ways of giving lessons, ability to do new techniques or in regulating the systematic process of presenting the ways of teaching and teaching methods. Based on the above problems, need to develop learning models in improving the results of learning smash punch skills in badminton games.

\section{Manuscipt preparation}

\subsection{Development of learning model}

Joyce, weil, danCalhom (2011) stated that a learning model is an illustration of a learning environment, which also includes teacher behavior when the model is applied. These models have many uses that reach all fields of education, starting from planning and curriculum material until to instructional planning material, including multimedia programs. Joyce and weil argued that learning model is a plan or pattern that can be used to design the curriculum (long-term learning plan), designing learning materials, guiding class or other learning (Rusman, 2012). The learning model can be used as a pattern of choice; it means that teachers can choose an appropriate and efficient learning model to achieve educational goals.

\subsection{Tutorial media video}

Learning media includes a tool which is physically used to convey the contents of teaching material, which consists of books, tape recorders, cassettes, video cameras, video recorders, films, slides, photos, pictures, graphics, television, and computers (Gagne and Briggs in AzharArsyad).

Tutorial video is (1) Classroom guidance by a teacher (tutor) for a student or a small group of students, (2) Additional teaching through tutors. Meanwhile, according to Amir Fatah (2008), video is a presentation of images and sounds captured by a camera, which is then arranged into a sequence of frames to be read in seconds.

In this study includes basic technical training materials for badminton game smash blows. The material is packaged in the form of a video tutorial with the help of video editing software that is wondersharefilmora.

Smash Badminton skills in badminton there are various basic techniques, including service, smash, lob, drop and footwork techniques. As stated by GiriVerianti (2007: 27) that, Basic skills of badminton can be divided into five parts:(1) serve, (2) smash, (3) overhead, (4) drive, and (5) drop." The five basic techniques of badminton games must be mastered by badminton players to support or achieve the goals of the game.

Poole (in Ahmad, et al), stated that Smash punch is the fastest and strongest blow, where the shuttlecock is hit hard and dropped down in empty areas or pointing to the opposing player's body. Whereas according to Syahri smash is smash is an overhead (top) trawl that is directed down and carried out with full power. 
Paper will be part of the conference proceedings therefore we ask that authors follow the guidelines explained in this example and in the file «FormatContentsForAuthors.pdf» also on the zip file, in order to achieve the highest quality possible (Smith, 1998).

Be advised that papers in a technically unsuitable form will be returned for retyping. After returned the manuscript must be appropriately modified.

\section{Method}

To be able to produce certain products, research is used in the form of needs analysis to test the effectiveness of the product so that it can function in the wider community, then research was needed to test the effectiveness of the product. So research and development were longitudinal (gradually it can be multy years) (Sugiyono, 2013).

The draft development research steps are as follows:

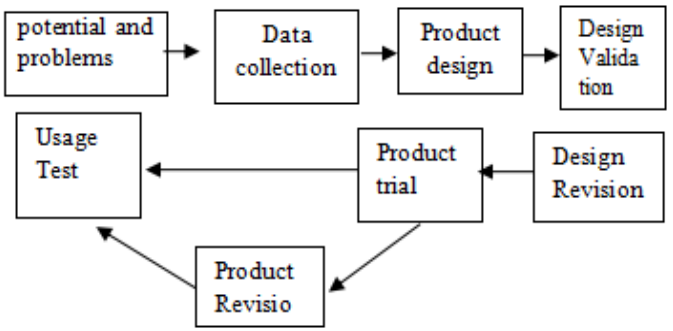

Figure 1.Steps for using the Research and Development (R \& D) method (Source: Sugiyono, 2013;409)

This development study classifies trial subjects into two, namely Subjects of trial experts, material experts and media experts. The subjects tested in this study were small (20 students) and for a large scale (60 students) badminton courses odd semester 2017/2018.

Data obtained through trial activities were classified into two, namely quantitative data and qualitative data. To find out whether there is a significant influence from this learning model through statistical methods (t-test).

\section{Discussion}

The results of data collection studies or the results of data collection studies or field findings are then described and analyzed so this result is descriptive and analytical by referring to the product to be produced. The following will be explained about the results of the learning model design validation test that will be developed by the researcher. 
Table 1. The Result of Validation

\begin{tabular}{|c|c|c|c|c|c|}
\hline \multirow{2}{*}{ No } & \multirow{2}{*}{ Model Name } & \multicolumn{2}{|c|}{ Receipt } & \multirow[t]{2}{*}{ Inf } & \multirow[b]{2}{*}{ Date } \\
\hline & & Yes & No & & \\
\hline 1 & $\begin{array}{l}\text { Model } 1 \\
\text { The basic } \\
\text { motion is } \\
\text { gradual } \\
\text { without cock }\end{array}$ & Yes & & $\begin{array}{l}\text { Valid / } \\
\text { Worthy }\end{array}$ & $\begin{array}{l}97,5 \\
0\end{array}$ \\
\hline 2 & $\begin{array}{l}\quad \text { Model } 2 \\
\text { Basic } \\
\text { movements of } \\
\text { hand } \\
\text { movements }\end{array}$ & Yes & & $\begin{array}{l}\text { Valid / } \\
\text { Worthy }\end{array}$ & $\begin{array}{l}97,5 \\
0\end{array}$ \\
\hline 3 & $\begin{array}{l}\quad \text { Model } 3 \\
\text { Overall basic } \\
\text { motion } \\
\text { without cock }\end{array}$ & Yes & & $\begin{array}{l}\text { Valid / } \\
\text { Worthy }\end{array}$ & $\begin{array}{l}97,5 \\
0\end{array}$ \\
\hline 4 & $\begin{array}{l}\text { Model } 4 \\
\text { Basic motion } \\
\text { of hand and } \\
\text { foot } \\
\text { combination }\end{array}$ & Yes & & $\begin{array}{l}\text { Valid / } \\
\text { Wo } \\
\text { rthy }\end{array}$ & $\begin{array}{l}97,9 \\
2\end{array}$ \\
\hline 5 & $\begin{array}{l}\quad \text { Model } 5 \\
\text { Basic } \\
\text { movements of } \\
\text { cock hand } \\
\text { movements }\end{array}$ & Yes & & $\begin{array}{l}\text { Valid / } \\
\text { Worthy }\end{array}$ & $\begin{array}{l}98,3 \\
3\end{array}$ \\
\hline 6 & $\begin{array}{l}\text { Model } 6 \\
\text { Hand foot } \\
\text { combination } \\
\text { motion with } \\
\text { cock }\end{array}$ & Yes & & $\begin{array}{l}\text { Valid / } \\
\text { Worthy }\end{array}$ & $\begin{array}{l}97,5 \\
0\end{array}$ \\
\hline 7 & $\begin{array}{l}\text { Model } 7 \\
\text { smash hull of } \\
\text { cock }\end{array}$ & Yes & & $\begin{array}{l}\text { Valid / } \\
\text { Worthy }\end{array}$ & $\begin{array}{l}97,0 \\
8\end{array}$ \\
\hline 8 & $\begin{array}{l}\text { Model } 8 \\
\text { smash line } \\
\text { service hull of } \\
\text { cock }\end{array}$ & Yes & & $\begin{array}{l}\text { Valid / } \\
\text { Worthy }\end{array}$ & $\begin{array}{l}97,9 \\
2\end{array}$ \\
\hline 9 & $\begin{array}{l}\text { Model } 9 \\
\text { central smash } \\
\text { hull field of } \\
\text { cock }\end{array}$ & Yes & & $\begin{array}{l}\text { Valid / } \\
\text { Worthy }\end{array}$ & $\begin{array}{l}98,3 \\
3\end{array}$ \\
\hline 10 & $\begin{array}{l}\text { Model } 10 \\
\text { smash base } \\
\text { line hull of } \\
\text { cock }\end{array}$ & Yes & & $\begin{array}{l}\text { Valid / } \\
\text { Worthy }\end{array}$ & $\begin{array}{l}96,6 \\
7\end{array}$ \\
\hline 11 & \begin{tabular}{lr}
\multicolumn{2}{c}{ Model 11} \\
cock & of \\
Smash & hull \\
left & field \\
\multicolumn{2}{l}{ service line }
\end{tabular} & Yes & & $\begin{array}{l}\text { Valid / } \\
\text { Worthy }\end{array}$ & $\begin{array}{l}97,9 \\
2\end{array}$ \\
\hline
\end{tabular}




\begin{tabular}{|c|c|c|c|c|}
\hline 12 & $\begin{array}{l}\text { Model } 12 \\
\text { cock of smash } \\
\text { hull left field } \\
\text { base line }\end{array}$ & Yes & $\begin{array}{l}\text { Valid / } \\
\text { Worthy }\end{array}$ & $\begin{array}{l}98,7 \\
5\end{array}$ \\
\hline 13 & $\begin{array}{l}\text { Model } 13 \\
\text { Smash the } \\
\text { movement } \\
\text { towards the } \\
\text { right front }\end{array}$ & Yes & $\begin{array}{l}\text { Valid / } \\
\text { Worthy }\end{array}$ & $\begin{array}{l}97,5 \\
0\end{array}$ \\
\hline 14 & $\begin{array}{l}\text { Model } 14 \\
\text { Smash the } \\
\text { movement to } \\
\text { the front left }\end{array}$ & Yes & $\begin{array}{l}\text { Valid / } \\
\text { Worthy }\end{array}$ & $\begin{array}{l}98,3 \\
3\end{array}$ \\
\hline 15 & $\begin{array}{l}\quad \text { Model } 15 \\
\text { Smash } \\
\text { Movement to } \\
\text { the right side }\end{array}$ & Yes & $\begin{array}{l}\text { Valid / } \\
\text { Worthy }\end{array}$ & $\begin{array}{l}98,7 \\
5\end{array}$ \\
\hline 16 & \begin{tabular}{l}
\multicolumn{1}{c}{ Mode 16} \\
Smash the \\
movement \\
towards the \\
left side
\end{tabular} & Yes & $\begin{array}{l}\text { Valid / } \\
\text { Worthy }\end{array}$ & $\begin{array}{l}98,7 \\
5\end{array}$ \\
\hline 17 & $\begin{array}{l}\text { Model } 17 \\
\text { Smash the } \\
\text { movement } \\
\text { towards the } \\
\text { right back }\end{array}$ & Yes & $\begin{array}{l}\text { Valid / } \\
\text { Worthy }\end{array}$ & $\begin{array}{l}98,3 \\
3 \\
\end{array}$ \\
\hline 18 & $\begin{array}{l}\text { Model } 18 \\
\text { Smash the } \\
\text { movement } \\
\text { towards the } \\
\text { left back }\end{array}$ & Yes & $\begin{array}{l}\text { Valid / } \\
\text { Worthy }\end{array}$ & $\begin{array}{l}96,6 \\
7 \\
\end{array}$ \\
\hline 19 & $\begin{array}{l}\text { Model } 19 \\
\text { Smash the } \\
\text { movement in } \\
\text { the middle } \\
\text { towards the } \\
\text { back }\end{array}$ & Yes & $\begin{array}{l}\text { Valid / } \\
\text { Worthy }\end{array}$ & $\begin{array}{l}97,9 \\
2\end{array}$ \\
\hline 20 & $\begin{array}{c}\text { Model } 20 \\
\text { Cross Smash }\end{array}$ & Yes & $\begin{array}{l}\text { Valid / } \\
\text { Worthy }\end{array}$ & $\begin{array}{l}98,7 \\
5\end{array}$ \\
\hline
\end{tabular}

Based on the large-scale test the development of the badminton smash punch learning model from 60 students obtained a percentage of $97.89 \%$.

Test results of the implementation hypothesis and the effectiveness of the badminton smash learning model that is carried out by the $\mathrm{t}$-test formula obtained $\mathrm{t}$ count $=9.76$ from the distribution list by using $1-\alpha=0,95$ with $\mathrm{dk} \mathrm{n}-1(60-1)=59$ obtained the price of $\mathrm{t}$ table 2.66. When compared, it is obtained thitung $>\mathrm{t}$ table, thus the badminton punch smash learning model of Faculty of Sports Science students, Medan State University effectiveness is used to improve the results of badminton smash punch learning skills.

The factor that makes the development of this model acceptable to students is from the aspect of media display in terms of ease of use of media, Material Demand, Color clarity of the picture, Material easily understood. Aspects of content and material in terms of Material 
Clarity, Picture Illustration clarify material and video to clarify material, so that the development model can be used to improve the learning outcomes of smash skills in badminton games.

\section{Conclusions}

The development of learning models using a gradual basic motion model without cock, basic motion models of hand movements, basic foot and hand combination motion model, the whole basic motion model without cock, basic motion models of cock hand movements, hand motion combination model with cock, smash hull cock model, smash line service hull cock model, central smash hull of cock model field, smash base line hull of cock model, smash hull left field service line of cock model, smash hull left field base line of cock model, smash movement model towards the right front, smash movement model towards the left front, smash movement model to the right side, smash movement model to the left side, smash movement model towards the right back, smash movement model towards the left back, smash movement model in the middle towards the back, cross smash model as a product that has been produced by researchers can be used as a learning model in the process of learning badminton smash blows..

\section{References}

[1] Agung Sunarno dan Syaifullah Sihombing.... Metode Penelitian Keolahragaan. Surakarta: Yuma Pustaka (2011)

[2] Ahmad Hasan dkk... Meningkatkan Pembelajaran Pukulan Forehand Lob Bulutangkis dengan menggunakan Part and Whole Method Pada Peserta Dididk Kelas VIII E SMP N 1 Winongan Kabupaten Pasuruan. Jurnal Pendidikan Jasmani. Vol.29. No.1 (2017)

[3] Amir Fatah dan Agus Purwanto.:. Digital Multimedia Animasi, Sound Editing, \& Video Editing. Yogyakarta :AndiOfset (2008)

[4] Azhar Arsyad.:. Media Pembelajaran. Jakarta: PT.Raja Grafindo Persada (2007)

[5] Ghazali dan Sugiyanto... Pengembangan Pembelajaran Teknik Dasar Bulutangkis Berbasis Multimedia Pada Atlet Usia 11 Dan 12 Tahun. Jurnal Keolahragaan. Vol4. No.2 (2016)

[6] Grice Tony.:. Bulu Tangkis Petunjuk Praktis Untuk Pemula Dan Lanjut. Jakarta: PT. Raja Grafindo Persada (1996)

[7] Hamdani.:. Strategi Belajar Mengajar. Bandung: PustakaSetia (2017)

[8] Harsono.:. Coaching dan Aspek-aspek Psikologis dalam Coaching. Jakarta: P2LPTK Ditjen Dikti Depdikbud, (1988)

[9] Joyce, B., Marsha Weil., Emily Calhoun.: Models of Teaching. Edisi Kedelapan. Yogyakarta. Pustaka Pelajar (2011)

[10] Komaruddin.:. Model Pembelajaran Aktif. Bandung: Remaja Rosdakarya (2000)

[11] M, Mosston and Ashwort, S.:. Teaching Physical Education (5th ed., (2002), dikutip langsung (atau tidak langsung) oleh Mark Byra (2002)

[12] Rusman.: Model-model Pembelajaran: Mengembangkan Profesionalisme Guru, Raja Grafindo Persada, Jakarta (2012)

[13] M. Sofyan.:. Permainan Bulutangkis. Jakarta: CV. Rikardo (2009)

[14] Sugiyono.:. Metode Penelitian Pendidikan Pendekatan Kuantitatif, Kualitatif, dan R\&D. Bandung: Alfabeta (2013)

[15] Syahrial Husin.:. Gemar Bermain Bulutangkis. Surakarta: CV. Seti-Aji (2007) 
